\title{
FACTORS ASSOCIATED WITH LOW ACHIEVEMENT IN POLIO IMMUNIZATION
}

\author{
(Faktor-Faktor Yang Berhubungan Dengan Rendahnya Cakupan Imunisasi Polio)
}

\author{
Reni Fitria, Sri Fawziyah, Erma Erfiana \\ Fakultas Ilmu Kesehatan Universitas Dharmas Indonesia \\ Email: Rhe86_dr.lirring@yahoo.co.id
}

\begin{abstract}
ABSTRAK
Pendahuluan: Kementerian Kesehatan Republik Indonesia telah menerapkan Imunisasi Polio 2016 secara serentak di Indonesia sejak 8 sampai 15 Maret 2016. Secara keseluruhan, hasil penerapan polio PIN di Kabupaten Dharmasraya pada tahun 2016 telah mencapai sekitar 93,15\%. Sementara skor terendah dicapai oleh Tiumang PHC 75,76\%. Tujuan dari penelitian ini adalah untuk mengetahui faktor-faktor yang berkaitan dengan rendahnya imunisasi polio pada bulan Maret 2016 di Puskesmas Tiumang Dharmasraya 2016. Metode: menggunakan analisis deskriptif dengan rancangan penelitian Cross-Sectional Study. Jumlah sampel adalah 94 orang dengan teknik accidental sampling. Dimana penelitian dilakukan di Puskemas Tiumang, Dharmasraya. Data dikumpulkan dengan menggunakan kuesioner yang kemudian diproses oleh perangkat lunak SPSS. Hasil: Hasil penelitian disajikan dalam bentuk frekuensi distribusi dan uji chi-square. Hasil penelitian menunjukkan bahwa hampir separuh dari 42 responden berpengetahuan (44,7\%), negatif (45,7\%), dan terendah $(3,2 \%)$ tidak memiliki kategori tindakan. Selanjutnya, hampir setengahnya didukung oleh keluarga negatif (30,9\%). Hasil uji statistik menemukan bahwa ( $\mathrm{p}$-value $=0,093$ ), tidak ada hubungan yang signifikan antara pengetahuan dan imunisasi polio. Selain itu, tidak ada hubungan yang signifikan antara sikap terhadap nilai imunisasi ( $\mathrm{p}$-value $=0,082$ ), tidak ada hubungan yang signifikan antara peran kader dan imunisasi polio ( $\mathrm{p}$-value $=0,591$ ). Namun, hanya dukungan keluarga yang bisa mencapai hubungan signifikan terhadap imunisasi ( $\mathrm{p}$-value $=0,005)$. Diskusi: Diharapkan ibu memperhatikan kesehatan anak-anak mereka agar tetap terjaga dan mereka yang belum termotivasi untuk mengunjungi anak mereka mendapatkan imunisasi polio.
\end{abstract}

Kata Kunci: Pengetahuan, sikap, dukungan keluarga, Imunisasi Polio

\begin{abstract}
Introduction: The Ministry of Health Republic of Indonesia has been implementing Polio Immunization (PIN) 2016 simultaneously in Indonesia since 8 to 15 March 2016. Overall, the result of implementation PIN polio at Dharmasraya regency in 2016 has reached about 93.15\%. Meanwhile, the lowest scored was reached by Tiumang PHC 75.76\%. The purpose of this research is to determine the factors associating on the low of reaching polio immunization in March 2016 at community health centers (Puskesmas) Tiumang Dharmasraya 2016. Methods: using descriptive analytic with CrossSectional Study research design. The number of samples is 94 people with accidental sampling technique. Where the research was conducted in Puskemas Tiumang, Dharmasraya. Data were collected using a questionnaire then processed by SPSS software. The result of the study is presented in the form of distribution frequency and chi-square test. Result: The study showed that almost half of 42 respondent were knowledgeable (44.7\%), negative (45.7\%), and the lowest $(3.2 \%)$ in no act category. Furthermore, almost half is supported by negative family (30.9\%). The result of the statistical test found that ( $p$-value $=0.093$ ), there is no significant relationship between knowledge and polio immunization. Moreover, there is no significant relationship between attitudes toward immunization values ( $p$-value $=0.082$ ), there is no significant relationship between the cadres roles and polio immunization ( $p$-value $=0.591$ ). However, only family support that can reach the significant relationship toward immunization ( $p$-values $=0.005)$. Discussions: $i$ is hoped that mothers concern about their children"s health to be kept and those who have not been motivated yet to visit with their children getting immunization polio.
\end{abstract}

Keywords: Knowledge, attitude, family support, Polio Immunization

\section{INTRODUCTION}

Immunization in the national health system is one of health interventions which is highly positive in reducing the number of mortality in the baby. The basic of primary health care, the preventive field is the most priority. By immunizing a child or baby, not only to protect the child but also impact on other children because of an increased level of public immunity and reduce the spread of infection (Ranuh et.al.).

Nowadays, the world, especially in developing countries, every 14.5 million children under five, die because of preventable 
diseases, malnutrition, and dehydration due to vomiting. Moreover, every year 3.5 million children under five die in diseases that actually can be prevented by immunization (Markum, 2002:159). Polio is still a health problem in Indonesia, where the cases of polio occurred in many areas in Indonesia. It prevents by the discovery of an outbreak of polio import that found in Sukabumi, West Java, in March 2005, there were 15 cases related to polio (Achmadi 2006:130).

Jacob John said, no polio is targeted to be achieved by 2020 . Therefore, the country is expected to introduce IPV in 2016 and attract an oral polio vaccine totally in 2020 . It is important as a final step to reduce polio. At the meeting, Indonesia addressed to be ready in gradually replace the oral vaccine.

Polio immunization is an immunization that provides an active immunity against poliomyelitis diseases. Polio is a disease that attacks the nerve inflammation which causes muscle pain and paralysis in one or both arms/ legs. Polio also can paralysis of respiratory and muscles to swallow. Polio can cause death. The transmission of polio is through the feces of infected people, saliva of patients, or contaminated food and drink. The purpose of giving immunization is expected children become immune to disease so as to reduce morbidity and mortality and also can reduce disability certainly.

The Ministry of Health has been implemented National Immunization Week (PIN) for Polio 2016 simultaneously throughout Indonesia from 8 to 15 March 2016. Except, Bali Province that will implement PIN on 15 to 22 March 2016. The last recapitulation, the implementation of PIN reached $96.4 \%$ of the total target baby 0-59 months in Indonesia. It means that 22.874.209 has been getting polio vaccine orally. These results are consistent with the target of Ministry of Health that children aged 0-59 months received immunization. (Kemenkes RI 2016).

Recapitulation of implementation PIN in Dharmasraya 2016 as entire coverage has reached 93.15\%. Pukesmas Sungai Dared had exceeded the target of 104 (96\%), while the lowest score achieved by Tiumang Puskesmas
$75.76 \%$ and the second lowest score was reached by Sungai Limau Puskesmas $82.15 \%$ (Dinkes Dharmasraya, 2016).

According to Notoatmojo, human behavior is reflected in various psychiatric symptoms as a factor that affects the motheres behavior to immunize their children related to maternal education, knowledge, desire, will, interest, motivation, and attitude. High-low immunization is influenced by the mother"s participation, officers attitude, and the distance between home and place of immunization, so on.

Based on the stated background above, the researcher needs to analyze and discover "Factors Associated with low achieving Polio Immunization in March 2016 PIN in Pukesmas Tiumang Dharmasraya 2016".

Firstly, to determine the frequency distribution of knowledge levels of the mother which have children against polio immunization in low achievement PIN March 2016. Secondly, to determine the frequency distribution of motherse attitude which has children against polio immunization in low achievement PIN March 2016. Thirdly, to determine the frequency distribution of the role of cadres who have babies and children against polio immunization in low achievement PIN March 2016. Fourthly, to determine the frequency distribution of family support to mothers which have children to polio immunization in low achievement PIN March 2016. Fifthly, to determine the frequency distribution of polio immunization in the PIN March 2016 in Puskesmas Tiumang 2016. Sixthly, to analyze the relationship of motherse knowledge against polio immunization in low achievement PIN March 2016 in Puskesmas Tiumang 2016. Seventhly, to analyze the relationship attitude toward mothers against polio immunization in low achievement PIN March 2016 in Puskesmas Tiumang 2016. Namely, to analyze the relationship of family support toward mothers which have children against polio immunization in low achievement PIN March 2016 at Pukesmas Tiumang.

The issues of PIN Polio Immunization in March 2016 towards 13 Puskesmas in Dharmasraya regency, the lowest achievement 
of immunization is achieved by Tiumang $75.76 \%$. Meanwhile, the government"s target is recommended $95 \%$ minimum target achievement. Therefore, this research discovers question of the low achievement in polio immunization PIN March 2016 at Puskesmas Tiumang. Where in this study, the researcher requires seeing which factors that lead to the low achievement of immunization. The factor that researcher want to research is mother knowledge, attitude, the role of cadres, and family support.

\section{Literature Review}

PIN Polio is a program to give additional polio immunization which targets to the group to achieve polio immunization regardless of immunization status based on the evaluation programs and epidemiological study. The primary purpose is to ensure the rate of Polio Immunity in the population (herd immunity) which covers more than $95 \%$ and provides optimal protection and equal in the age group of 0-59 months for the possibility of polio cases caused by the Sabin poliovirus. Targets whole children ages 0 to 59 month without looking to immunization status and will be held from March 8 to 15, 2016. Immunization Location in Posyandu, Polindes, Poskesdes, Health Centers, Private Clinic and Hospital including other immunization services under the coordination of local health department. PIN Polio Study in mothers who have babies in Puskesmas Tiumang is obtained from 6 people in the interview, 4 mothers come with their baby on the PIN Polio in March 2016. Meanwhile, 2 mothers did not bring their children due to their fear of being paralyzed. Knowledge is the result of understanding, and this occurred after people commit to an object. In human senses, namely the senses of sight, smell, touch and feel. Apart from human knowledge is obtained through the eyes and ears (Notoatmodjo, 2012). The level of knowledge according to Notoatmodjo 2012, knowledge is covered by cognitive domain has six level; knowing, understanding, application, analysis, synthesis, and evaluation. Knowledge previous study the result of interviewing with a mother who has babies in Puskesmas
Tiumang, based on six people in interviews, four mothers know about the implementation PIN Polio in March 2016 and the importance of bringing children to Posyandu to immunize Polio to their child. However, two mothers know that should bring their child to PIN Polio Immunization in March, but they did not come because they sad that their understanding in Polio is contained by pork polio and polio causes paralysis.

Attitude is a certain persones $\mathrm{s}$ reaction or response toward stimulus or a particular object, which has already involved opinion factors and emotions (happy-unhappy, agree-disagree, good-worse, and so on) (Notoadmojo 2017 in Fery Pretty, 2011).Classification Attitude: the first positive attitude is people who show acceptance, recognition, agreeing which tend to approach and please a particular object. The last result of positive attitude is an attitude that leads to right action. The second is the negative attitude of someone who shows rejection or disagrees in the tendency of avoiding certain object then lead to wrong action Notoadmojo (2003) in Feri Jelita (2011). Preliminary Studies the mother"s attitude who have babies in Puskesmas Tiumang from six people in interviews, four people have a positive attitude to support government programs on PIN Polio in March and come with their child to Posyandu.

The role of Cadre: for health workers are expected to ready anytime to explain or prepare the immunization consulting rooms in the health center Brochures about immunization should be copied more with simple language to be easy in understanding for parent level education, particularly mothers. Non-profit organizations must help this. In general, people who have more information of need more explanation about their health, children"s health, including their immunization status. The effort in order to people behave and adopt a healthy life by persuasion, inducement, appeal, solicitation, and giving an intervention which is delivered to behavior, in order to its condition become conducive. Moreover, health education is purposed to individuals, groups, or communities have a positive effect on the maintenance and improvement of 
health. For getting effective in intervention, they need to be done before diagnosing and analyzing to a behavior problem. Preliminary Study of Cader Role: the result of interviews with mothers who have babies in Puskesmas Tiumang reached from six people said that the cadres and health professional to every home to provide brochures about polio immunization in March ago.

Family Support Freidman (1992) defines the family who has two or more individual who cooperates in emotional, and family is a father, mother and their children and divide the task based on their gender (Potter \& Perry, 2005). Factors Affecting the Family Support Feiring and Lewis (1984) in Friedman (1998), there is strong valid evidence from previous research that large family and small family qualitatively describe their experience of growth. Children who come from a large family. In addition, the support given by parent (especially mothers) are also affected by age. According to Friedman (1998), according to Friedman (1998), young mother tend not to feel more or recognize the needs of their children and also more egocentric than older. Other Factors that affect family support is economic status. Socio-economic include parent" income level and education level. In a middle-class family, a relationship that more authority or autocracy seems to exist. Furthermore, parents live in the medium social call have support level, affection and higher engagement than a parent with lower social class. Preliminary Study: the result of interviews showed that mothers who have babies in Puskesmas Tiumang, six people. Four mothers said no family support for their children in order to visit PIN Polio, while the others said no family support to visit the PIN Polio March 2016.

\section{METHODS}

The method used is descriptive analytic with cross sectional study research design. The population of this research is whole mothers who have babies in Puskesmas Tiumang Dharmasraya 2016. The sampling technique used was accidental sampling with 94 people. Operational definition of this research is a reaction or response from mothers who have opinions about the factors involved PIN Polio March with positive statements and negative statements of the mother and the mother agreed and disapproval towards immunization

The research was conducted on 18 to 29 July 2016 in Puskesmas Tiumang Dharmasrya Regency, West Sumatera. The number of samples in this research were 94 respondents. This research is supported by health professionals, especially Puskesmas Tiumang which hold the immunization program. Data collected by distributing questionnaires to the mothers who have babies in Puskesmas Tiumang. After collecting data, it is counted by computerized data processing, using editing, coding, data entry, cleaning, and tabulation. Furthermore, data analysis, univariate data analysis to determine each variable frequency, and bivariate analysis in order to look the relationship between independent and dependent variable tested by Chi-Square test. 
Table 1

\begin{tabular}{|c|c|c|c|c|c|c|}
\hline No. & Variable & $\begin{array}{c}\text { Operational } \\
\text { Definition }\end{array}$ & Instrument & Test & Result & $\begin{array}{c}\text { Measuring } \\
\text { Scale }\end{array}$ \\
\hline 1 & Knowledge & $\begin{array}{l}\text { Knowledge or } \\
\text { everything is } \\
\text { related to maternal } \\
\text { immunization on } \\
\text { PIN March. }\end{array}$ & questionnaire & $\begin{array}{l}\text { Asking } 10 \\
\text { Question if the } \\
\text { answer: } \\
\text { Yes }=1 \\
\text { No }=0\end{array}$ & $\begin{array}{l}\text { High } 76-100 \% \\
\text { Medium } 55-75 \% \\
\text { Low }<55 \% \\
\text { (Wawan,2011) }\end{array}$ & Ordinal \\
\hline 2 & Attitude & $\begin{array}{l}\text { Reaction or response } \\
\text { from mother who } \\
\text { have opinions about } \\
\text { factors involved PIN } \\
\text { Polio March with } \\
\text { positive and negative } \\
\text { statements of mother. } \\
\text { And also agree- } \\
\text { disagree statement. }\end{array}$ & questionnaire & $\begin{array}{l}\text { Rated by } 4 \text { for } \\
\text { question with } \\
\text { point statement. } \\
-\mathrm{SS}=4 \\
-\mathrm{S}=3 \\
-\mathrm{TS}=2 \\
\mathrm{STS}=1\end{array}$ & $\begin{array}{l}\text { Positive: } \\
\geq \text { median } \\
\text { Negative: } \\
\text { < median } \\
\text { (Budiarto, 2002) }\end{array}$ & Ordinal \\
\hline 3 & Cadre Role & $\begin{array}{l}\text { readiness or the } \\
\text { presence of cadres } \\
\text { to help explain or } \\
\text { prepare consultations } \\
\text { and health education } \\
\text { about polio } \\
\text { immunization in } \\
\text { health centers to } \\
\text { mothers who have } \\
\text { babies. }\end{array}$ & questionnaire & $\begin{array}{l}\text { Asking } 10 \\
\text { questions if the } \\
\text { answers: } \\
\text { Yes }=1 \\
\text { No }=0\end{array}$ & $\begin{array}{l}\text { Participation } \\
\geq 60 \% \text { with total } \\
\text { point } \geq 6 \text {. } \\
\text { No Participation } \\
<60 \% \text { with total } \\
\text { point }<6\end{array}$ & Ordinal \\
\hline 4 & $\begin{array}{l}\text { Family } \\
\text { Support }\end{array}$ & $\begin{array}{l}\text { Support or } \\
\text { motivation is given } \\
\text { by family (husband, } \\
\text { parents, parents in } \\
\text { law, even others } \\
\text { relative) in } \\
\text { giving polio } \\
\text { immunization. }\end{array}$ & Questionnaire & $\begin{array}{l}\text { Asking } \\
10 \\
\text { questions if the } \\
\text { answers: } \\
\text { Yes }=1 \\
\text { No }=0\end{array}$ & $\begin{array}{l}\text { Positive: } \\
\geq \text { median } \\
\text { Negative: } \\
\text { <median } \\
\text { (Budiarto, 2002) }\end{array}$ & Ordinal \\
\hline 5 & $\begin{array}{l}\text { Imunisasi } \\
\text { Polio }\end{array}$ & $\begin{array}{l}\text { Imunisasi should be } \\
\text { done in PIN Polio } \\
\text { March } 2016 .\end{array}$ & Questionnare & Documentation & $\begin{array}{l}\text { - Treat } \\
\text { - No Treat }\end{array}$ & Ordinal \\
\hline
\end{tabular}

\section{RESULT}

Based on table 2 it can be seen that 42 people $(44.7 \%)$ were knowledgeable respondent in Polio Immunization in the PIN March 2016.

Based on table 3 shows that half of respondent were negative 43 (45.7\%) on Polio Immunization in the PIN March 2016.

Table 4 shows that the number of respondent who did not play a role were 3
(3.2\%). However, almost entirely respondent answered 91 people $(96.8 \%)$ which contributed to the cadre in polio immunization PIN March 2016.

According to Table 5 prevents from 94 respondent, 8 people $(8.5 \%)$ did not bring their children to PIN Polio March 2016.

Based on table 6 it can be seen that there is no significant relationship between knowledge and polio immunization by p-value 
Table 2. Knowledge level of mothers who have babies and children against polio immunization in low achievement PIN March 2016

\begin{tabular}{clcc}
\hline No. & Knowledge & Frequency & $\mathbf{\%}$ \\
\hline 1 & High & 38 & 40.4 \\
2 & Medium & 42 & 44.7 \\
3 & Low & 14 & 14.9 \\
Total & & 94 & 100 \\
\hline
\end{tabular}

Table 3. the attitude of mothers who have baby and children against polio immunization in low achievement PIN March 2016.

\begin{tabular}{llcc}
\hline No. & Attitude & Frequency & \% \\
\hline 1 & Negative & 43 & 45.7 \\
2 & Positif & 51 & 54.3 \\
Total & & 94 & 100 \\
\hline
\end{tabular}

Table 4. the role of cadre mother about the low achievement of polio immunization PIN March 2016.

\begin{tabular}{llcc}
\hline No. & Cadre Role & Frequency & \% \\
\hline 1 & No act & 3 & 3.2 \\
2 & act & 91 & 96.8 \\
Total & & 94 & 100 \\
\hline
\end{tabular}

Table 5. Mothers' family support who have babies and children against polio immunization in low achievement PIN March 2016.

\begin{tabular}{llcc}
\hline No. & $\begin{array}{c}\text { Family } \\
\text { Support }\end{array}$ & Frequency & $\mathbf{\%}$ \\
\hline 1 & Negative & 29 & 30.9 \\
2 & Positif & 65 & 69.1 \\
Total & & 94 & 100 \\
\hline
\end{tabular}

Table 6. Relationship knowledge of mothers with babies and children against polio immunization in low achievement PIN March 2016 in Puskesmas Tiumang 2016.

\begin{tabular}{llccccccc}
\hline \multirow{2}{*}{ No } & \multirow{2}{*}{ Knowledge } & \multicolumn{4}{c}{ Giving Polio Immunization } & \multirow{2}{*}{ Total } & \multirow{2}{*}{ p-value } \\
\cline { 3 - 7 } & & \multicolumn{2}{c}{ No treat } & \multicolumn{2}{c}{$\begin{array}{c}\text { Giving } \\
\text { treat }\end{array}$} & & \\
\cline { 2 - 7 } & & $\mathbf{F}$ & $\mathbf{\%}$ & $\mathbf{f}$ & $\mathbf{\%}$ & $\mathbf{f}$ & $\mathbf{\%}$ & \\
\hline 1 & Low & 3 & 3.2 & 11 & 11.7 & 14 & 14.9 & 0.093 \\
2 & Medium & 4 & 4.3 & 38 & 40.4 & 42 & 44.7 & \\
3 & High & 1 & 1.1 & 37 & 39.4 & 38 & 40.4 & \\
& Total & 8 & 8.5 & 86 & 91.5 & 94 & 100 & \\
\hline
\end{tabular}

$\mathrm{X}^{2}$ Hitung $=4.743 \quad \mathrm{X}^{2}$ Tabel $=5.991$

Table 7. Relations attitude to mothers have babies and children against polio immunization in low achievement PIN March 2016 in Puskesmas Tiumang 2016.

\begin{tabular}{|c|c|c|c|c|c|c|c|c|}
\hline \multirow{3}{*}{ No } & \multirow{3}{*}{ Attitude } & \multicolumn{4}{|c|}{ Giving Polio Immunizaton } & \multirow{2}{*}{\multicolumn{2}{|c|}{ Total }} & \multirow{3}{*}{ p-value } \\
\hline & & \multicolumn{2}{|c|}{ No treat } & \multicolumn{2}{|c|}{ treat } & & & \\
\hline & & $\mathbf{F}$ & $\%$ & f & $\%$ & f & $\%$ & \\
\hline 1 & Negatif & 6 & 6.4 & 37 & 39.4 & 43 & 45.7 & 0.082 \\
\hline \multirow[t]{2}{*}{2} & Positif & 2 & 2.1 & 49 & 52.1 & 51 & 54.3 & \\
\hline & Total & 8 & 8.5 & 86 & 91.5 & 94 & 100 & \\
\hline
\end{tabular}

$\mathrm{X}^{2}$ Hitung $=3.015 \quad \mathrm{X}^{2}$ Tabel $=3.841$ 
Table 8. Relationship role of cadres to the low achievement of polio immunization PIN March 2016 in Puskesmas Tiumang 2016.

\begin{tabular}{|c|c|c|c|c|c|c|c|c|}
\hline \multirow{3}{*}{ No } & \multirow{3}{*}{ Cadre Role } & \multicolumn{4}{|c|}{ Giving Polio Immunization } & \multirow{2}{*}{\multicolumn{2}{|c|}{ Total }} & \multirow{3}{*}{ p-value } \\
\hline & & \multicolumn{2}{|c|}{ No Treat } & \multicolumn{2}{|c|}{ Treat } & & & \\
\hline & & $\mathbf{F}$ & $\%$ & f & $\%$ & f & $\%$ & \\
\hline 1 & No action & 0 & 0 & 3 & 3.2 & 3 & 3.2 & 0.591 \\
\hline \multirow[t]{2}{*}{2} & Action & 8 & 8.5 & 83 & 88.3 & 91 & 96.8 & \\
\hline & Total & 8 & 8.5 & 86 & 91.5 & 94 & 100 & \\
\hline
\end{tabular}

$\mathrm{X}^{2}$ Hitung $=0.288 \quad \mathrm{X}^{2}$ Tabel $=3.841$

Table 9. Relations family support for low achievement of polio immunization PIN March 2016 in Puskesmas Tiumang 2016

\begin{tabular}{|c|c|c|c|c|c|c|c|c|}
\hline \multirow{3}{*}{ No } & \multirow{3}{*}{ Family Support } & \multicolumn{4}{|c|}{ Giving Polio Immunization } & \multirow{2}{*}{\multicolumn{2}{|c|}{ Total }} & \multirow{3}{*}{ p-value } \\
\hline & & \multicolumn{2}{|c|}{ No treat } & \multicolumn{2}{|c|}{ Treat } & & & \\
\hline & & $\mathbf{F}$ & $\%$ & f & $\%$ & f & $\%$ & \\
\hline 1 & Negative & 6 & 6.4 & 23 & 24.5 & 29 & 30.9 & 0.005 \\
\hline \multirow[t]{2}{*}{2} & Positive & 2 & 2.1 & 63 & 67 & 65 & 69.1 & \\
\hline & Total & 8 & 8.5 & 86 & 91.5 & 94 & 100 & \\
\hline
\end{tabular}

$>0.05$, which $\mathrm{X}^{2}$ count 4.743 and $\mathrm{X}^{2}$ table 5.991. Hence, $X^{2}$ counted $<X^{2}$ it means Ha is rejected, but Ho is accepted.

According to Table 7 showed that there is no significant relationship between attitude and Polio immunization with $\mathrm{p}>0.05, \mathrm{X}^{2}$ count 3.015 and $X^{2}$ table 3.841 where $X^{2}$ numbered $<X^{2}$, it means that $\mathrm{Ha}$ is rejected and Ho is vice versa.

Table 8 presents that there is no significant relationship between role cadre and giving Polio Immunization with $\mathrm{p}>0.05$, where $\mathrm{X}^{2}$ is 0.288 and $\mathrm{X}^{2}$ table $3.841 . \mathrm{X}^{2}$ counted $<$ $\mathrm{X}^{2}$ table it means that $\mathrm{Ha}$ is rejected and Ho is Accepted.

According to table 9 above shows that there is a significant relationship between family support related to giving polio immunization with $p p \leq 0.05$, where $X^{2}$ values are 7.989 , and the $X^{2}$ table is 3.841 where $X^{2}$ count $>X^{2}$ table. So, it means that $\mathrm{Ha}$ is accepted and Ho is rejected.

\section{DISCUSSION}

Based on the result of 94 respondent partly 8 people $(8.5 \%)$ did not bring their children to PIN Polio Immunization March 2016. However, Widiyati (2012) in research conducted at Sragen City on Polio Immunization presented that different result where 122 respondent (73\%) visit immunization with their children. Low achievement of polio immunization for mothers who have a baby is influenced by human behavior; it can be seen that almost half of respondent were 42 people in knowledgeable (44.7\%), nearly half of respondent were negative $43(45.7 \%)$. Many of cadres tend not to play role 3 (3.2\%). Meanwhile almost half of the respondent answered that there is no family support 29 people $(30.9 \%)$ towards polio immunization.

Mothers are imperative to the growth of their children, particularly in maintaining and preventing illness. Then the motheres $s$ behavior like knowledge be-be improved in obtaining and seeking information about polio immunization. For example, counseling in Puskesmas, leaflets, TV, and poster. Moreover, the mother should have a good response and positive when getting information about immunization. Good family support is required by a mother like providing transportation to bring their children immunization, scheduled 
reminded, looking for information. Cadre should be active to provide information to the mothers so that mothers who have babies will understand the existence of polio immunization program.

Knowledge factor did not influence maternal immunization against polio. Although the mother is often exposed about PIN Polio March 2016, many of them still did not bring their children be immunized. They rejected for various reasons. For example, it was forbidden by husband because vaccines contain pork. The Indonesian Ulema Council (MUI) had explained that the vaccine does not contain pork, but they still have a principle to reject. Hence, they did not bring their children to get the immunization.

Attitude did not totally affect maternal immunization against polio. Although the mother had a positive response in giving immunization, they also did not bring their children to PIN March 2016. The attitude that shows acceptance, recognition, agreeing to tend to approach and please in PIN Polio March 2016. As a result, the mother will take their children to be immunized against polio. However, someone who shows rejection and disagrees is likely to avoid PIN Polio March 2016. The will act in wrong way where did not bring their children to be immunized. Even though, PIN Polio is held by government purposes to increase immunization against child immunity. Therefore, mother motivation should be increased to get the immunization.

There is no relationship in the role of cadres, but the result of questionnaire shows that entirely answered was involved in March 2016. Cadre has attempted to provide information to mothers who have babies in order to bring their children to PIN Polio March 2016. Cadres also visit door to door to provide leaflets about the PIN Polio March 2016, and also picked to the mothers who cannot come on the specified schedule. Moreover, cadres convince mothers about the importance of polio immunization. However, they refused to take their children on Mother"s PIN Polio March 2016. They still in principle to not immunizing children.
The family is very important for this issues: husband and wife. Good family support toward PIN Polio March 2015 makes mothers more interesting to bring their children. Moreover, supported like preparing vehicle, accompanied to immunization place, schedule reminder, and giving attention when going to childes immunization. They were very proud when carrying the child to be immunized. Families will remain and upset if the mother did not want to bring children. Good family support will change the mother spirit come on PIN Polio March 2016 and make children enjoyable in Polio Immunization.

\section{CONCLUSIONS}

The result of this study can be concluded as follows: Nearly half of the respondents were knowledgeable about polio immunization in the PIN March 2016. Almost half of respondent are negative about polio immunization in March 2016. Many cadres did not play a role and almost entirely contribute to the provision of PIN Polio Immunization in March 2016. Mostly half of the respondents answered negatively about the family support. Furthermore, it can be seen that small portion of respondents did not bring the child to be immunized PIN in March 2016. Therefore, there is a significant relationship between knowledge, family support, and polio immunization. While there is no significant relationship between attitude, the role of cadre and polio immunization.

For health centers is expected to guide health worker to immunization program continuously and provide information and counseling about immunization, which is delivered to the mothers who have babies in Puskesmas Tiumang, Posyandu, and training to volunteers in order to make them more active in running Posyandu. For instance, conducting a healthy baby contest. For mothers are hoped to concern about their children"s health and keep maintaining. And for those who have no motivation, is expected to motivation themselves, active in participating by skipping homework and discard the rational 
principle in order to bring their children in polio immunization. (PDPI 2011; Notoatmodjo 2003)

\section{REFERENCES}

Aziz, Alimul, 2008. Pengantar Ilmu Kesehatan Anak untuk pendidikan Kebidanan. Jakarta: Salemba Medika

Dalal, A, Silveira, M, 2005, Indian Pediatrics, vol.42, pp. 401

Depkes, 2010. Keputusan Menteri Kesehatan Republik Indonesia Nomor: 482/ Menkes/SK/IV/2010 Tentang Gerakan Akselerasi Imunisasi Nasional Universal Child Immunization 2010-2014. Jakarta: Departemen Kesehatan RI.

Fitria Reni 2007. Hubungan tingkat pengetahuan dan sikap ibu yang mempunyai bayi balita tentang imunisasi dasar di Puskesmas Ulak karang Padang tahun 2007. STIKes Mercubaktijaya Padang.

Friedman, 2003. Family Nursing Research, Theory and Practice. New Jersey: Prentice Hall. Ghazali, et al, 2008. Studi cross-sectional. Dalam Sastroasmoro, S. \& Ismael, S. Dasar-dasar Metodologi penelitian klinis.(3rd Ed). Jakarta :Sagung Seto

IDAI, 2011. Pedoman Imunisasi di Indonesia. Jakarta: Badan Penerbit Ikatan Dokter Anak Indonesia

Kemenkes RI, 2015. Petunjuk Teknis Pekan Imunisasi Nasional (PIN) Polio tahun 2016. Kemenkes RI, 2016. Buku Saku Petunjuk Teknis Tenaga Kesehatan Di Lapangan.
Marimbi, Hanum, 2010. Tumbuh Kembang, Status Gizi, dan Imunisasi Dasar pada Balita.Jogjakarta: Nuha Medika.

Notoatmodjo, S. 2003. Pendidikan dan perilaku. Jakarta:RinekaCipta.

Notoatmodjo, S. 2007.Promosi Kesehatan dan Ilmu Perilaku. Jakarta: RinekaCipta,

Notoatmodjo, S. 2010.Ilmu Perilaku Kesehatan. Jakarta: RinekaCipta.

Notoatmodjo, S. 2012.Metodologi Penelitian Kesehatan. Jakarta: RinekaCipta.

Odusanya, OO, et al 2008, , Determinants of vaccination coverage in rural Nigeriaee, BMC Public Health, vol. 8, pp. 381.

Proverati, A. 2010. Imunisasi Dan Vaksin. Yogyakarta: Medika Pressindo

Putri Syah, 2013. Untuk mengetahui hubungan antara pengetahuan, tingkat pendidikan dan peran kader Posyandu terhadap pemberian imunisasi pada bayi di wilayah kerja Puskesmas Patalassang Kabupaten Takalar. Stikes Nani Hasanudin

Rahmaika Dita, 2015. Faktor-faktor yang berhubungan dengan status imunisasi dasar pada bayi Di kelurahan Mergosono Kecamatan Kedungkandang Kota Malang. Stikes Maharani Malang

Setiadi, 2008. Konsep dan proses keperawatan keluarga Edisi 1. Yogyakarta: Graha Ilmu.

Widayati Nur, 2012. Hubungan tingkat pengetahuan ibu tentang imunisasi polio Dengan status kelengkapan imunisasi polio di wilayah kerja Puskesmas Tanon I Sragen. Stikes Aisyiyah Surakarta 